\title{
Assessment of health-related quality of life and patient's knowledge in chronic non- specific low back pain
}

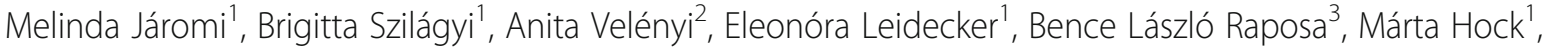
Petra Baumann ${ }^{3}$, Pongrác Ács ${ }^{1}$ and Alexandra Makai ${ }^{1 *}$

\begin{abstract}
Background: Chronic non-specific low back pain syndrome (cnsLBP) is a severe health problem in developed countries, which has an important effect on patients' quality of life and is highly determined by socio-demographic factors and low back pain specific knowledge. We examined patients' health-related quality of life according to the results of the Short Form Health Survey (SF-36), low back pain knowledge (LBPKQ) and the social determinants of the participants.
\end{abstract}

Methods: We carried out our research in the first half of 2015 in Southern Transdanubia, Hungary. The examination included 1155 respondents living with chronic non-specific low back pain. The confidence interval of 95\% was used, and the level of. significance was $p<0.05$ using SPSS 22.0 software.

Results: The SF-36 questionnaire is suitable for the examination of patients' health-related quality of life (Cronbach's Alpha> 0.76), as the LBPKQ's Cronbach's Alpha was 0.726 also, which showed good validity. Longer-term disease meant a lower health-related quality of life $(p<0.05)$. A greater decrease of function (Roland Morris scores (RM)) accounts for a lower HRQoL and higher knowledge level. We found significant differences in LBPKQ scores according to sociodemographic parameters. The general health status was positively correlated with LBPKQ $(p=$ 0.024) adjusted for demographic and pain and functional status.

Conclusion: The negative effect of the symptoms on patients' quality of life is proved, which is determined by different socio-demographic parameters furthermore by knowledge. Above all could be useful information for professionals to adopt the right interventions.

Keywords: Low back pain, Health-related quality of life, Short form health survey, Roland Morris disability questionnaire, Social determinants

\footnotetext{
* Correspondence: alexandra.makai@etk.pte.hu

${ }^{1}$ Institute of Physiotherapy and Sports Science, Faculty of Health Sciences,

University of Pécs, Vörösmarty u. 3., Pécs H-7621, Hungary

Full list of author information is available at the end of the article
}

(c) The Author(s). 2021 Open Access This article is licensed under a Creative Commons Attribution 4.0 International License, which permits use, sharing, adaptation, distribution and reproduction in any medium or format, as long as you give appropriate credit to the original author(s) and the source, provide a link to the Creative Commons licence, and indicate if changes were made. The images or other third party material in this article are included in the article's Creative Commons licence, unless indicated otherwise in a credit line to the material. If material is not included in the article's Creative Commons licence and your intended use is not permitted by statutory regulation or exceeds the permitted use, you will need to obtain permission directly from the copyright holder. To view a copy of this licence, visit http://creativecommons.org/licenses/by/4.0/ The Creative Commons Public Domain Dedication waiver (http://creativecommons.org/publicdomain/zero/1.0/) applies to the data made available in this article, unless otherwise stated in a credit line to the data. 


\section{Background}

Chronic non-specific low back pain syndrome (cnsLBP) is a severe health problem in developed countries. Low back pain (LBP) syndrome can be classified according to the duration of the pain as well as the causes triggering the pain. Based on the duration of the pain it can be acute, subacute or chronic. In the case of acute LBP pain lasts for up to 6 weeks, in case of subacute LBP lumbosacral pain lasts from 6 to 12 weeks. Having chronic LBP pain stays for more than 12 weeks. In the case of nonspecific LBP diagnosis, a clarified cause can be defined only in $15 \%$ of the cases [1-4].

Prevalence of chronic LBP (cnsLBP) among adults is $60 \%[1,5]$. Prevalence of cnsLBP is strongly associated with several socio-demographic determinants: it is increased by age, being the most characteristic musculoskeletal disorder among middle-aged adults. Women are more commonly affected as well as people performing sedentary occupations or hard physical work including heavy-weight lifting [6-8]. Moreover, obesity can be named as a risk factor for cnsLBP syndrome [5].

Furthermore, the effect of the disease is notable for social and economic subsystems also because in developed societies cnsLBP is the most common reason for a leave of absence from work [9]. The financial burden caused by cnsLBP syndrome has a significant effect on the financing of our healthcare system in Hungary, too [10-16].

Waxman et al. examined the correlation between cnsLBP and symptoms of depression. Pain encourages the patient to tackle the disease, influences the quality of life, and decreases life satisfaction $[9,10]$.

Nevertheless, studies on quality of life examine the indirect expenses of cnsLBP from the point of view of the individual and also their impact on subjective quality of life, in terms of how much the average of the patients' HRQoL dimensions differs from the one of healthy population or how much it changes after certain treatments had been applied [17-19].

From the 1990s on the number of studies about quality of life has multiplied in the field of medical-sanitary research; Veresciagina et al. as well as studies of Dahl et al. proved that 36-Item Short Form Health Survey (SF-36) questionnaire is suitable to measure cnsLBP patients' quality of life $[18,19]$.

Patients do not have adequate knowledge on the quantity of physical activity and the type of physical activity that can be performed in cnsLBP [20,21]. Also, patients have little information on how to replace some of the possibly painful activities with other movements in a different way. For healthy and patients with LBP, patient education programs or back school programs can help prevent and rehabilitate spine prevention knowledge or disease specific knowledge [22].
In many diseases, prevention and rehabilitation programs supplemented with patient education are more effective. A patient with a better disease specific knowledge, who understands the cause, pathomechanism of the disease, has the right knowledge of prevention and treatment options, can participate more effectively and actively in prevention or rehabilitation. Thus, patient education is an essential part of primary prevention, to prevent the disease, secondary prevention to reduce the impact of the disease, and tertiary prevention to soften the impact of the illness [23-26].

Weckbach et al. examined 248 patients low back pain knowledge, where they found that only $32.6 \%$ of them could respond correctly to the knowledge scale questions [25]. Patients do not have adequate knowledge on the quantity of physical activity and the type of physical activity that can be performed in cnsLBP [20, 21]. Also, patients have little information on how to replace some of the possibly painful activities with other movements in a different way. For healthy and patients with LBP, patient education programs or back school programs can help prevent and rehabilitate spine prevention knowledge or disease specific knowledge [22].

One of the objectives of our research is to assess the quality of life (HRQoL) of nscLBP syndrome patients and the functional status of the spine, testing the validity of the HRQoL scale and comparing the scales with healthy adults's mean values. We hypothesized that the socio-demographic parameters, self-rated physical disability (RMDQ - Roland Morris Disability Questionnaire) and low back pain specific knowledge (LBPKQ) would determine significantly the HRQoL measures by SF-36of nscLBP patients. This study aims help the better understanding of the disease and encourage health care workers to considering socio-demographic and knowledge factors also in planning interventions.

\section{Methods \\ Study design and setting}

Patients with cnsLBP (participating in physiotherapy treatment) were recruited into a cross-sectional, observational study between 1 January - 15 July 2015 in Southern Transdanubia, Hungary.

The study based on a convenience sample. Inclusion criteria: patient treated in the Southern Transdanubian region, of age over 18, with chronic ongoing for at least 12 weeks) non-specific low back pain. Exclusion criteria: acute and subacute low back pain syndrome, low back pain with non-musculoskeletal origins (gynecological, retroperitoneal, abdominal), spine surgery in the preceding 6 months, chronic pain syndrome, depression.

The method of our research was a paper and pencil questionnaire that furthermore contained an information sheet about the details of the research and ethical 
information stating that by filling in the questionnaire the respondent agrees to take part in the study.

This study followed the principles of the Declaration of Helsinki, ethics approval number: ETT TUKEB 5739/2015).

\section{Measures}

The present research consisted of three validated standard questionnaires and a demographic questionnaire designed by our team.

\section{Quality of life}

The 36-Item Short Form Health Survey (SF-36) [27] was used to measure patients' HRQoL, which is adapted for respondents over the age of 14 and validated in Hungary [28]. The summary scores of the different items can be derived (range: 0-100) with higher scores indicating better HRQoL. Quality of life is evaluated according to eight different dimensions: Physical functioning (PF), Physical role functioning (RP), Bodily pain (BP), General health $(\mathrm{GH})$, Vitality (VT), Social role functioning (SF), Emotional role functioning (RE), Mental Health $(\mathrm{MH})$.

\section{Disease-specific knowledge}

The assessment of spine prevention and low back pain disease-specific knowledge was performed with validated Low back pain knowledge questionnaire [24]. The questionnaire consists of 16 single or multiple-choice questions. The questions can be divided into three categories: (1) general knowledge about lower back pain, spinal anatomy and biomechanics, (2) definitions related to lower back pain, (3) prevention and treatment of lower back pain. The maximum score of the questionnaire is 24 points [24, 26].

\section{Spine functional state}

Roland Morris Disability Questionnaire (RMDQ) was used to measure the functional status of the spine. The 24-item RMDQ can be applied in the cases of acute, subacute and chronic low back pain patients to measure the functional status and the decreased function of the lumbar spine during daily physical activity. The questionnaire has been validated in Hungary, its maximum score being 24 that indicates decreased function/restraint, value 0 implies the maximum $[29,30]$.

\section{Statistical analysis}

Descriptive statistics were used to summarize demographic parameters. The continuous variables were analysed by using non-parametric statistical tests (Kruskal-Wallis test, the Mann-Whitney U test and Sperman's rank correlation). Multiple regression analysis was performed using a linear regression model to identify the determinants of HRQoL for the SF-36. Cronbach's alpha was used to measure the instruments' internal consistency. SPSS 24.0 was used for all data analyses and all $p$-values $<0.05$ were indicated as being of a statistical significance adjusting also for multiple comparisons.

\section{Results}

Patients with cnsLBP were recruited into our crosssectional study, through selection 1500 forms were planned to be included in our research; after falling-off (due to rejection or exclusion because of inadequate filling in) 1155 participants (439 female, 716 male) were included. Their mean age was $45.25 \pm 16.90$.

Among 1155 participating cnsLBP patients the ratio of women was $61.99 \%$, two-thirds of the respondents were town residents, $46.03 \%$ of them were married. Based on their age $(p=0.17)$ and place of residence $(p=0.35)$ no significant difference was found between genders. According to their marital status, the ratio of the married was significantly higher among men (50.93\%), the ratio of the widow was higher among women (9.99\%). 65.89\% possessed secondary level qualification, among men the ratio of those having a lower qualification is significantly lower $(p<0.01) .67 .53 \%$ are active employees (among women the ratio of the inactive is significantly higher: $35.99 \%(\mathrm{p}<0.01), 56.45 \%$ of respondents do sedentary work.

They first experienced the symptoms of cnsLBP syndrome $15.28 \pm 12.55$ years ago on the average. To RMDQ, measuring the functional status of the spine, respondents gave the average value of $4.81 \pm 4.59$, a significant difference between genders was not found (Table 1).

The reliability of the SF-36 questionnaire was examined by testing the Cronbach's Alpha values of the 8 dimensions, based on the values above 0.76 the internal consistency of the questionnaire is considered acceptable.

Respondents evaluated all HRQoL dimensions with significantly lower scores compared to the healthy population (except for Social functioning (SF) dimension that resulted in lower value but showing no significant difference $(p=0.24)[28]$. According to the results of SF-36 questionnaire respondents evaluated their general health $(\mathrm{GH})$ with an average of $55.69 \pm 20,86$ scores out of 100 (which score indicates excellent health conditions). The lowest evaluation was given to the VT dimension $(53.45 \pm 19.91)$, indicating low levels of vitality and vivaciousness of nscLBP patients. The measure of BP dimension among nscLBP patients was, as expected, unfavourable $(64.24 \pm 23.07)$. Restraints originating from their disease were present during work as well (PR: $63.94 \pm 38.71$ ) (Table 2).

The validity of the LBPKQ was examined, the Cronbach's Alpha $=0.72$. The mean LBPKQ score was $7.81 \pm$ 
Table 1 The socio-demographic characteristics of cnsLBP patients

\begin{tabular}{|c|c|c|c|c|c|}
\hline & & $\begin{array}{l}\text { Total sample }(N= \\
1157)\end{array}$ & $\begin{array}{l}\text { Female } \\
(61.99 \%)\end{array}$ & $\begin{array}{l}\text { Male } \\
(38.01 \%)\end{array}$ & $\begin{array}{l}\text { Differences between } \\
\text { gender }(p)\end{array}$ \\
\hline \multicolumn{2}{|c|}{ Age (standard deviation (SD)) } & $45.25 \pm 16.90$ & $45.89 \pm 17.34$ & $\begin{array}{l}44.16 \pm \\
16.10\end{array}$ & 0.17 \\
\hline \multirow[t]{3}{*}{ Place of living } & county town & $28.41 \%$ & $30.29 \%$ & $25.49 \%$ & 0.35 \\
\hline & city & $42.34 \%$ & $40.63 \%$ & $45.10 \%$ & \\
\hline & village & $29.25 \%$ & $29.08 \%$ & $29.41 \%$ & \\
\hline \multirow[t]{5}{*}{ Marital status } & single & $22.18 \%$ & $21.38 \%$ & $23.61 \%$ & $<0.01$ \\
\hline & married & $46.03 \%$ & $43.04 \%$ & $50.93 \%$ & \\
\hline & cohabitated & $15.63 \%$ & $15.61 \%$ & $15.74 \%$ & \\
\hline & divorced & $9.17 \%$ & $9.99 \%$ & $7.64 \%$ & \\
\hline & widow & $6.99 \%$ & $9.99 \%$ & $2.08 \%$ & \\
\hline \multirow[t]{3}{*}{ Education } & low & $5.71 \%$ & $7.00 \%$ & $3.40 \%$ & $<0.01$ \\
\hline & medium & $65.89 \%$ & $49.40 \%$ & $58.00 \%$ & \\
\hline & high & $28.40 \%$ & $43.60 \%$ & $38.60 \%$ & \\
\hline \multirow{2}{*}{$\begin{array}{l}\text { Employment } \\
\text { status }\end{array}$} & employed & $67.53 \%$ & $64.01 \%$ & $74.20 \%$ & $<0.01$ \\
\hline & other - inactive (student. Retired etc.) & $32.47 \%$ & $35.99 \%$ & $25.80 \%$ & \\
\hline \multirow[t]{4}{*}{$\begin{array}{l}\text { Employment } \\
\text { form }\end{array}$} & $\begin{array}{l}\text { sedentary work less that } 30 \text { min physical } \\
\text { activity }\end{array}$ & $24.10 \%$ & $28.06 \%$ & $18.77 \%$ & $<0.01$ \\
\hline & $\begin{array}{l}\text { sedentary work with more than } 30 \text { min } \\
\text { physical activity }\end{array}$ & $32.35 \%$ & $37.19 \%$ & $25.85 \%$ & \\
\hline & light physical labour & $30.41 \%$ & $26.73 \%$ & $35.38 \%$ & \\
\hline & heavy physical labour & $13.14 \%$ & $8.02 \%$ & $20.00 \%$ & \\
\hline \multicolumn{2}{|c|}{ RMDQ (maximum 24 point) - mean (SD) } & $4.81 \pm 4.59$ & $4.81 \pm 4.54$ & $4.80 \pm 4.68$ & 0.63 \\
\hline \multicolumn{2}{|c|}{ Time spent after the first episode of cnsLBP (years) } & $15.28 \pm 12.55$ & $15.48 \pm 12.82$ & $\begin{array}{l}15.27 \pm \\
12.52\end{array}$ & 0.65 \\
\hline
\end{tabular}

2.68. We tested the LBPKQ score differences according to different socio-demographic parameters and we found significant differences in scores by age, education, place of living, work type and marital status also (Table 3).

In the course of our examination we assumed that the increase of the years spent since the first episode of lowback pain implies a further decrease in the quality of life of cnsLBP patients. Regarding all 8 dimensions of the questionnaire significant correlation was found between the number of years spent in pain and the mean value of the certain HRQoL dimension ( $\mathrm{p}<0.05)$.

Among the examined scores weak correlation was found $(\mathrm{R}<0.30)$, except for PF that showed medium strength correlation with the number of years, indicating significantly decreased function by the ongoing of years $(\mathrm{R}=-0.41 ; p<0.01)$ (Table 4).

Table 2 Reliability and internal consistency of the different SF-36 dimensions (Cronbach's Alpha) [29]

\begin{tabular}{|c|c|c|c|c|}
\hline & \multirow[t]{2}{*}{ Healthy population - normal values [25] } & \multicolumn{2}{|c|}{ cnsLBP patients } & \multirow[b]{2}{*}{$\mathbf{p}$} \\
\hline & & Mean & Standard deviation & \\
\hline General health (GH) & 64 & 55.69 & 20.86 & $<0.01$ \\
\hline Bodily pain (BP) & 78 & 64.24 & 23.07 & $<0.01$ \\
\hline Social function (SF) & 80 & 76.86 & 23.77 & 0.24 \\
\hline Mental health (MH & 71 & 67.34 & 19.38 & $<0.01$ \\
\hline Vitality (VT) & 70 & 53.46 & 19.91 & $<0.01$ \\
\hline Role emotional (RE) & 78 & 73.69 & 37.24 & 0.02 \\
\hline Role physical (RP) & 79 & 63.94 & 38.71 & $<0.01$ \\
\hline Physical function (PF) & 91 & 74.67 & 23.19 & $<0.01$ \\
\hline
\end{tabular}


Table 3 LBPKQ scores mean according to the sociodemographic parameters

\begin{tabular}{|c|c|c|c|c|}
\hline \multicolumn{5}{|l|}{ LBPKQ scores } \\
\hline & & Mean & SD & $p$ \\
\hline \multirow[t]{5}{*}{ Age groups } & $18-29$ & 8.29 & 2.64 & \multirow{5}{*}{$\begin{array}{l}< \\
0.01\end{array}$} \\
\hline & $30-39$ & 7.69 & 2.78 & \\
\hline & $40-49$ & 7.86 & 2.52 & \\
\hline & $50-59$ & 7.79 & 2.69 & \\
\hline & $60+$ & 7.26 & 2.71 & \\
\hline \multirow[t]{2}{*}{ Gender } & female & 7.91 & 2.74 & \multirow[t]{2}{*}{0.09} \\
\hline & male & 7.66 & 2.58 & \\
\hline \multirow[t]{3}{*}{ Education } & low & 6.20 & 2.35 & \multirow{3}{*}{$\begin{array}{l}< \\
0.01\end{array}$} \\
\hline & middle & 7.70 & 2.63 & \\
\hline & high & 8.39 & 2.70 & \\
\hline \multirow[t]{2}{*}{ Place of living } & urban & 7.98 & 2.65 & \multirow{2}{*}{$\begin{array}{l}< \\
0.01\end{array}$} \\
\hline & rural & 7.38 & 2.69 & \\
\hline \multirow{2}{*}{$\begin{array}{l}\text { Having a paid } \\
\text { work }\end{array}$} & yes & 7.89 & 2.62 & \multirow{2}{*}{0.15} \\
\hline & no & 7.67 & 2.73 & \\
\hline \multirow[t]{4}{*}{ Work type } & $\begin{array}{l}\text { sitting, less than } 30 \mathrm{~min} \\
\text { activities }\end{array}$ & 8.10 & 2.57 & \multirow[t]{4}{*}{0.03} \\
\hline & $\begin{array}{l}\text { sitting, more than } 30 \text { min } \\
\text { activities }\end{array}$ & 8.22 & 2.69 & \\
\hline & light work & 7.67 & 2.58 & \\
\hline & heavy work & 7.39 & 2.53 & \\
\hline \multirow[t]{5}{*}{ Marital status } & single & 8.19 & 2.65 & \multirow{5}{*}{$\begin{array}{l}< \\
0.01\end{array}$} \\
\hline & cohabitating & 7.79 & 2.63 & \\
\hline & married & 8.07 & 2.68 & \\
\hline & divorced & 7.30 & 2.51 & \\
\hline & widow & 6.98 & 2.86 & \\
\hline
\end{tabular}

Results of RMDQ was significantly correlated with all 8 HRQoL dimensions $(\mathrm{p}<0.01)$ (showing negative weak or medium strength correlation) (Table 4).

LBPKQ was showed a significant positive correlation with general health, pain, social function and role of physical health (Table 4.).

Table 4 Correlations between the time spent since the first episode of LBP, RM, LBPKQ and HRQOL

\begin{tabular}{llll}
\hline & Diagnosed & RM & LBPKQ \\
\hline General health (GH) & $-0.27^{*}$ & $-0.4^{*}$ & $0.11^{*}$ \\
Bodily pain (BP) & $-0.29^{*}$ & $-0.59^{*}$ & $0.06^{*}$ \\
Social function (SF) & $-0.17^{*}$ & $-0.46^{*}$ & $0.07^{*}$ \\
Mental health (MH) & $-0.06^{*}$ & $-0.29^{*}$ & $0.04^{* *}$ \\
Vitality (VT) & $-0.14^{*}$ & $-0.39^{*}$ & $-0.02^{* *}$ \\
Role emotional (RE) & $-0.09^{*}$ & $-0.27^{*}$ & $0.02^{* *}$ \\
Role of physical health (RP) & $-0.23^{*}$ & $-0.52^{*}$ & $0.08^{*}$ \\
Role of physical functioning (RP) & $-0.41^{*}$ & $-0.58^{*}$ & $0.04^{* *}$ \\
\hline $\mathrm{p}<0.05^{*} ; p>0.05 * *$ & & &
\end{tabular}

We examined the relationship between SF-36 HRQoL dimensions and LBPKQ scores and the found positive significant correlation only in general health status ( $R$ square: 0.17, $\mathrm{F}=24.16, p<0.01)$, Beta constant: 56.95, Beta LBPKQ: $0.58 p=0.02$ ) adjusting for functional status and socio-demographic parameters (age, gender, education, place of living, work type, RM).

\section{Discussion}

CnsLBP is a notable health problem of modern societies in addition its symptoms result in the significant decrease of HRQoL in patients' lives, more or less corresponding to socio-demographic parameters and LBP specific knowledge [31].

Several studies have proven that SF-36 questionnaire, used in the present research, is suitable for examining HRQoL of nscLBP patients: Kogure et al. [32] examined the efficiency of Arthrokinematic Approach-Hakata treatment; Tavafian et al. [33] analyzed in their research the quality of life of a LBP group participating in a Back School and a clinical treatment; Buynak et al. [34] examined the quality of life of three LBP groups, two of them receiving two kinds of opioid treatment and the third one receiving placebo; Adorno et al. [30] in their research subjected 30 patients to isostretching and global postural re-education interventions and examined the quality of life of the participants of the two treatments using SF-36 questionnaire. All of the above mentioned as well as the present research confirm the fact that the quantitative method may be adequate when examining the quality of life of nscLBP patients. Regarding the results of SF-36 dimensions the following was shown in the research of Kogure et al.: GH: $38.0 \pm 8,1, \mathrm{BP}: 31.8 \pm$ 6.7, SF: $33.4 \pm 12.8, \mathrm{MH}: 41.2 \pm 8.9$, VT: $39.6 \pm 8.78, \mathrm{RE}$ : $35.0 \pm 12.5$, RF: $28.9 \pm 13.3$, PF: $30.1 \pm 14.0$ [35], in the study of Tavafian et al.: GH:41.7 \pm 22.2 , BP: $42.6 \pm 25.3$, SF: $62.5 \pm 29.8, \mathrm{MH}: 47.8 \pm 23.5, \mathrm{VT}: 48.9 \pm 21.6, \mathrm{RE}:$ $32.7 \pm 40.4, \mathrm{RP}: 31.7 \pm 35.0, \mathrm{PF}: 52.5 \pm 20.2$ [32]. In comparison, the results found in the present research account for more favourable HRQoL, which may be caused by the fact that the set of patients taking part in studies specifying mostly interventions have a more serious nscLBP syndrome. Furthermore, the results of the RM questionnaire also confirm these findings (4.81 \pm 4.59).

The HRQoL results found in our research proved to be significantly lower than normal values of the healthy population, except for Social Functioning (SF) dimension that although fell behind the mean value of the healthy population by a few score points, it did not differ significantly among nscLBP patients. Therefore, on the whole it can be stated that regarding social function the examined patients' judgement on social function does not differ from the one of healthy population [27]. 
In our survey, the participants' low back pain prevention knowledge was between $6.20-8.39$ points. We also found similar results in international literature Maciel et al. [24] measured 46-year-old participants who did not receive a spine prevention education program, their point was 8.6 points. In the King of Saud University survey, 40-year-old participants who did not receive spine prevention education achieved 9 points [35].

Patients who participated in education and back school programs reached $16-22.2$ points $[24,26]$. The disease-specific knowledge of health workers was 19.119.2 points [26, 36] (Table 5).

In our research the LBPKQ was showed a significant positive correlation with general health, pain, social function and role of physical health, which fact has important role in planning the future interventions for cnsLBP patients.

While examining the quality of life of patients bearing nscLBP syndrome our research has proven that chronic pain has a notable effect on patients' quality of life. The longer nscLBP syndrome has been present in patients' lives, the less favourable their quality of life is. The disease accounts for greater and greater measures of restraint regarding functional, bodily and mental health. Similar results were found when comparing RMDQ and SF-36 results: the greater the level of pain and restraint is, the more unfavourable the patients' bodily and mental health is, furthermore the more unfavourable social function turns into. In our research patients evaluated the functional status of their spine $4.81 \pm 4.59$ through RMDQ. The functional status of the spine of nscLBP patients participating in international studies resulted diverse. On the whole it can be stated that studies specifying interventions are characterized by higher RMDQ values while quantitative research as the present one found lower values (Table 6) [37-40].

According to the regression analysis our finding is that the RMDQ sum value is strongly and significantly associated with all of the 8 dimensions of HRQoL, which furthermore attests that functional drawbacks originating from the disease have an impact on all fields of HRQoL.

Among socio-demographic determinants, the significant effect of sitting for more than $30 \mathrm{~min}$ has been proven for the most dimensions followed by age and gender. Hence, sedentary work, the rise of age or belonging to female gender account for the highest risk on the decrease of quality of life among acLBP patients. Sedentary work accounts for a higher risk of a decrease in quality of life also in comparison with hard physical work. As it is also confirmed by our research that women, among whom the evolution of nscLBP is more frequent, evaluate their quality of life more unfavourably than men, therefore the disease means a greater burden for them, what calls for particular attention during treatment. (HRQoL was proved to be lower among women regarding $\mathrm{BP}, \mathrm{SF}, \mathrm{RE}, \mathrm{PF}$ dimensions). The rise of age results in the decrease of HRQoL considering GH, BP, RP, PF dimensions. In the sample of the present research the elderly age-group is not represented, only the middle-aged and the aging along with the young, which fact must be taken into consideration when examining and evaluating age.

Table 5 Systematic summary of disease-specific knowledge

\begin{tabular}{|c|c|c|c|}
\hline Author/Year of publication & Place of the research & Sample (N) & LBPKQ sum value \\
\hline Maciel et al $2009[24]$ & Federal University of Sao Paulo & $\begin{array}{l}30 \\
46 \text { years } \\
\text { no education }\end{array}$ & 8.6 \\
\hline Awwad et al 2016 [35] & King Saud University & $\begin{array}{l}153 \\
40 \text { years } \\
\text { no education }\end{array}$ & 9.0 \\
\hline Kovács-Babócsay et al 2019 [26] & University of Pécs, Hungary & $\begin{array}{l}54 \\
42 \text { years } \\
\text { no education }\end{array}$ & 12.3 \\
\hline Author/Year of publication & Place of the research & Sample (N) & LBPKQ sum value \\
\hline Maciel et al 2009 [24] & Federal University of Sao Paulo & $\begin{array}{l}30 \\
46 \text { years } \\
\text { back school program- education }\end{array}$ & 16.0 \\
\hline Kovács-Babócsay et al 2019 [26] & University of Pécs, Hungary & $\begin{array}{l}54 \\
42 \text { years } \\
\text { back school program- education }\end{array}$ & 22.2 \\
\hline Author/Year of publication & Place of the research & Sample (N) & LBPKQ sum value \\
\hline Morimoto et al 2018 [36] & Hospital Sao Paulo - Universidade & $\begin{array}{l}60 \\
31.7 \text { years } \\
\text { health care workers }\end{array}$ & 19.2 \\
\hline Kovács-Babócsay et al 2019 [26] & University of Pécs, Hungary & $\begin{array}{l}55 \\
32 \text { years } \\
\text { health care workers }\end{array}$ & 19.1 \\
\hline
\end{tabular}


Table 6 Results of RMDQ in different international researches

\begin{tabular}{llll}
\hline Author/Year of publication & Place of the research & Sample size (N) & RMDQ sum value (standard deviation) \\
\hline van Helvoirt et al 2014 [37] & Netherlands & 69 & $7.00-15.40$ \\
Ghadyani et al 2016 [38] & Iran & 136 & $5.95-6.37$ \\
Takahashi et al 2016 [39] & Japan & 102 & $6.68(1.57)-9.52(1.60)$ \\
\hline
\end{tabular}

According to further findings among nscLBP patients possessing qualifications in higher education general health and physical functioning are more favourable in comparison with patients with lower education that may be explained by the assumption that people with higher education devote more attention and apply a wider range of treatment options, resulting in a higher quality of life. Moreover, low education has a significantly negative effect on social and mental health as well that reinforces nscLBP patients' exclusion and the accumulation of further negative effects [5-7].

Regarding marital status, confirming data coming from literature, divorced and single respondents replied with less favourable values in case of dimensions concerning mental health, that proves the health preserving and improving effect, also in the case of chronic diseases, of cohabitation and marriage [9] (Table 4).

\section{Limitations}

However, there are some important limitations of our research that should be mentioned in the present study. Firstly, our sample is not representative, the ratio of city residents is high while one of people with low education is low. Also, the sample was recruited exclusively from people coming from the Southern Transdanubia, therefore it cannot be generalized to the whole Hungarian population - conclusions in that concern can be drawn only when considering the mentioned limitation. Secondly, the HRQoL and RMDQ were measured using self-administered questionnaires, which could give bias.

\section{Conclusions}

The present study confirmed that SF-36 is reliable to measure the HRQoL of nscLBP patients, furthermore, the patients' HRQoL was significantly lower than the healthy populations. The LBP specific knowledge was significantly correlated with HRQoL. The age, gender women, sitting (job) was negatively associated with most of the physical and mental HRQOL, and higher education or paid job were positively associated with physical or social HRQOL. Finally, if the marital status is divorced or single, it was negatively associated with mental HRQoL. According to these significant sociodemographic determinants an even more specific and well-aimed intervention can be framed in order to improve the HRQOL of this population.

\section{Abbreviations}

(SF-36): Short Form Health Survey; (LBPK): Low back pain knowledge; (RM): Roland Morris; (cnsLBP): Chronic non-specific low back pain syndrome; (LBP): Low back pain; (RMDQ): Roland Morris Disability Questionnaire; (PF): physical functioning; (RP): role limitations due to physical problems; (BP): bodily pain; $(\mathrm{GH})$ : general health; (VT): vitality; (SF): social functioning; $(\mathrm{RE})$ : role limitations due to emotional problems; $(\mathrm{MH})$ : and mental health

\section{Acknowledgements}

Not applicable.

\section{About this supplement}

This article has been published as part of BMC Public Health Volume 21 Supplement 1, 2021: Level and Determinants of Physical Activity in the V4 Countries - Part 2. The full contents of the supplement are available online at URL. https://bmcpublichealth.biomedcentral.com/articles/supplements/ volume-21-supplement-1.

\section{Authors' contributions}

All authors read and approved the final manuscript. MJ, AM and AP conceived, designed and managed the study, contributed to the data collection and analysis, and to the drafting and final editing of the manuscript, BSZ, AV, EL, LBR, MH and PB contributed in collection of participants and data.

\section{Funding}

The publication costs were partially funded by the 20765/3/2018/ FEKUTSTRAT grant. The authors declare that the study design; collection, management, analysis, and interpretation of data; writing of the manuscript are independent of the grant.

\section{Availability of data and materials}

The dataset supporting the conclusions of this article is available from the corresponding author on reasonable request.

\section{Ethics approval and consent to participate}

The ethical approval was granted for the study by the Ethics Committee of University of Pécs (Nr. 5739/2015). Participants were informed about the research aim and methods before signing the informed consent form. The investigation conforms to the principles outlined in the Declaration of Helsinki.

Consent for publication

Not applicable.

\section{Competing interests}

The authors declare that they have no competing interests.

\section{Author details}

${ }^{1}$ Institute of Physiotherapy and Sports Science, Faculty of Health Sciences, University of Pécs, Vörösmarty u. 3., Pécs H-7621, Hungary. ²Department of Neurosurgery, Clinical Center, University of Pécs, Rét utca 2, Pécs H-7623, Hungary. ${ }^{3}$ Faculty of Health Sciences, University of Pécs, Vörösmarty u. 4, Pécs H-7621, Hungary.

Received: 31 January 2021 Accepted: 1 February 2021

Published: 23 April 2021

\section{References}

1. Bálint G. The modern international principles of diagnosing and treating low back pain (a derékfájás diagnosztikájának és kezelésének modern nemzetközi elvei). Lege Artis Medicinae. 2011;21(5):329-35. 
2. Koes BW, van Tulder M, Lin CW, Macedo LG, McAuley J, Maher C. An updated overview of clinical guidelines for the management of non-specific low back pain in primary care. Eur Spine J. 2010;19(12):2075-94.

3. Adams MA, Burton K, Bogduk N: The Biomechanics of Back Pain, vol. 55: Elsevier Health Sciences; 2012.

4. Deyo RA, Weinstein JN. Low back pain. N Engl J Med. 2001:344(5):363-70.

5. Horváth G, Than P, Bellyei Á, Kranicz J, Illes T. Musculoskeletal complaints frequency of adults and adolescents - Representative survey of South West Hungary 10 thousand samples (Mozgásszervi panaszok gyakorisága felnőtt és serdülőkorban - Reprezentatív felmérés a Dél-Dunántúlon 10 ezer fős mintából). Orv Hetil. 2006;147(8):351-6.

6. Biglarian A, Seifi B, Bakhshi E, Mohammad K, Rahgozar M, Karimlou M, Serahati S. Low back pain prevalence and associated factors in Iranian population: findings from the national health survey. Pain Res Treat. 2012; 2012:653060.

7. Andersson GB, Lucente T, Davis AM, Kappler RE, Lipton JA, Leurgans S. A comparison of osteopathic spinal manipulation with standard care for patients with low back pain. N Engl J Med. 1999;341(19):1426-31.

8. Oláh A, Sándor J, Boncz I, Betlehem J. A kistérségi egyenlőtlenségek az otthoni szakápolás vonatkozásában a dél-dunántúli térségben. Nővér. 2004;17(5):17.

9. Waxman SE, Tripp DA, Flamenbaum R. The mediating role of depression and negative partner responses in chronic low back pain and relationship satisfaction. Journal of Pain. 2008;9(5):434-42.

10. Ács P, Hécz R, Paár $D$, Stocker M. A fittség ( $m$ ) értéke : A fizikai inaktivitás nemzetgazdasági terhei Magyarországon. Közgazdasági Szemle. 2011;58(7-8):689.

11. Jaromi M, Nemeth A, Kranicz J, Laczko T, Betlehem J. Treatment and ergonomics training of work-related lower back pain and body posture problems for nurses. J Clin Nurs. 2012;21(11-12):1776-84.

12. Boncz I, Nagy J, Sebestyen A, Korosi L. Financing of health care services in Hungary. Eur J Health Econ. 2004;5(3):252-8.

13. Acs P, Stocker M, Fuge K, Paar D, Olah A, Kovacs A: Economic and public health benefits: the result of increased regular physical activity. Eur J Integrative Med 2016, 8(2 Suppl.) 8-12.

14. Alsiddiky AM, Algarni N, Alluhaidan A. Prevalence and associated factors of low Back pain among clinicians of a major referral hospital. Med J Malays. 2015;70(1):12-7.

15. van Middelkoop M, Rubinstein SM, Kuijpers T, Verhagen AP, Ostelo R, Koes BW, van Tulder MW. A systematic review on the effectiveness of physical and rehabilitation interventions for chronic non-specific low back pain. Eur Spine J. 2011;20(1):19-39.

16. Ács P, Stocker M, Oláh A. The determination of economic and public health benefits achievable by increasing regular physical exercise. Apstract Applied Studies in Agribusiness and Commerce. 2013;8(1):5-14.

17. Dagenais S, Caro J, Haldeman S. A systematic review of low back pain cost of illness studies in the United States and internationally. Spine J. 2008;8(1):8-20.

18. Veresciagina K, Ambrozaitis KV, Spakauskas B. Health-related quality-of-life assessment in patients with low back pain using SF-36 questionnaire. Medicina. 2007;43(8):607-13.

19. Dahl B, Gehrchen PM, Kiaer T, Blyme P, Tondevold E, Bendix T. Nonorganic pain drawings are associated with low psychological scores on the preoperative SF-36 questionnaire in patients with chronic low back pain. Eur Spine J. 2001;10(3):211-4.

20. Ács P, Betlehem J, Oláh A, Bergier B, Morvay-Sey K, Makai A, Prémusz V. Cross-cultural adaptation and validation of the Global Physical Activity Questionnaire among healthy Hungarian adults. BMC Public Health. 2020; 20(Suppl 1):1056. https://doi.org/10.1186/s12889-020-08477-z.

21. Ács P, Betlehem J, Oláh A, Bergier J, Melczer C, Prémusz V, Makai A. Measurement of public health benefits of physical activity: Validity and reliability study of the International Physical Activity Questionnaire in Hungary. BMC Public Health. 2020;20(Suppl1):1198. https://doi.org/10.1186/ s12889-020-08508-9.

22. Nolet PS, Kristman VL, Cote P, Carroll LJ, Cassidy JD. The association between a lifetime history of low back injury in a motor vehicle collision and future low back pain: a population-based cohort study. Eur Spine J. 2018;27(1):136-44

23. Kálcza-Jánosi K, Lukács A, Barkai L, Szamosközi I. The validation of the diabetic knowledge questionnaire DKQ-24 on Transylvanian Hungarian population (a diabetic knowledge questionnaire DKQ-24 validálása erdélyi magyar populáción). Egészségtudományi Közlemények. 2013;3(1):91-8.

24. Maciel SC, Jennings F, Jones A, Natour J. The development and validation of a low Back pain knowledge questionnaire - LKQ. Clinics. 2009;64(12):1167-75.

25. Weckbach S, Kocak T, Reichel H, Lattig F. A survey on patients' knowledge and expectations during informed consent for spinal surgery: can we improve the shared decision-making process? Patient Safety Surgery. 2016;10:15.

26. Kovacs-Babocsay B, Makai A, Szilagyi B, Tardi P, Acs P, Velenyi A, Rebek-Nagy $\mathrm{G}$, Jaromi M. The Hungarian translation and validation of the low Back pain knowledge questionnaire (Egy deréktáji fájdalommal kapcsolatos betegségspecifikus tudást felmérő külföldi kérdőív hazai, magyar nyelvű validálása). Orv Hetil. 2019;160(42):1663-72.

27. Czimbalmos Á, Nagy Z, Varga Z, Husztik P. Patients satifactions study with SF-36 questionnaire, the definition of normal values in HUngary (Páciens megelégedettségi vizsgálat SF-36 kérdőívvel, a magyarországi normálértékek meghatározása). Népegészségügy. 1999;80(1):4-19.

28. Valasek T, Pal VP, Istvan K, Zsolt S, Arpad B. The measurement of decreased function of lumbar spine (Az ágyéki gerinc funkciócsökkenésének mérése: Négy önkitöltôs, ágyékigerinc-specifikus állapotfelmérô kérdôiv magyar nyelvi adaptálása és validálása). Ideggyógyászati Szemle. 2015;68:3-4.

29. Ormos G, Czimbalmos Á, Csiki J, Huszták P, Szabó C. Validation process of two specific low back pain questionnaires (Két derékfájásspecifikus állapot felmérős index hazai validálása). Rehabilitáció. 2014;24(2-3):65-8.

30. Adorno ML, Brasil-Neto JP. Assessment of the quality of life through the SF36 questionnaire in patients with chronic nonspecific low back pain. Acta Ortopedica Brasileira. 2013;21(4):202-7.

31. Roland M, Morris R. A study of the natural history of low-back pain. Part II: development of guidelines for trials of treatment in primary care. Spine. 1983;8(2):145-50.

32. Kogure A, Kotani K, Katada S, Takagi H, Kamikozuru M, Isaji T, Hakata S. A randomized, single-blind, placebo-controlled study on the efficacy of the Arthrokinematic approach-Hakata method in patients with chronic nonspecific low Back pain. PLoS One. 2015;10(12):e0144325

33. Tavafian SS, Jamshidi A, Mohammad K, Montazeri A. Low back pain education and short term quality of life: a randomized trial. BMC Musculoskelet Disord. 2007;8:21.

34. Buynak R, Shapiro DY, Okamoto A, Van Hove I, Rauschkolb C, Steup A, Lange $B$, Lange C, Etropolski M. Efficacy and safety of tapentadol extended release for the management of chronic low back pain: results of a prospective, randomized, double-blind, placebo- and active-controlled phase III study. Expert Opin Pharmacother. 2010;11(11):1787-804.

35. Awwad WM, Alfayez SM, Bin Dous AN, Alrabiei QA, Altowim AA, Almutair AS, Arafah O. Knowledge around back pain and spinal disorders among Saudi patients: a cross-sectional study. J Pakistan Med Assoc. 2017;67(8):1228-31

36. Morimoto $\mathrm{HC}$, Jones A, Natour J. Assessment of gesture behavior and knowledge on low back pain among nurses. Advances Rheumatol. 2018;58(1):27

37. van Helvoirt H, Apeldoorn AT, Ostelo RW, Knol DL, Arts MP, Kamper SJ, van Tulder MW. Transforaminal epidural steroid injections followed by mechanical diagnosis and therapy to prevent surgery for lumbar disc herniation. Pain Med. 2014;15(7):1100-8.

38. Ghadyani L, Tavafian SS, Kazemnejad A, Wagner J. Development and psychometric evaluation of nursing low Back pain predictor questionnaire focusing on nurses suffering from chronic low Back pain in Iran. Asian Spine J. 2016;10(4):697-704.

39. Takahashi N, Shirado O, Kobayashi K, Mashiko R, Konno S. Classifying patients with lumbar spinal stenosis using painDETECT: a cross-sectional study. BMC Fam Pract. 2016;17:90.

40. Tarfarosh SF, Lone BU, Beigh MI, Manzoor M. An innovative and portable multimodal pain relief device for the Management of Neuropathic low Back Pain - a study from Kashmir (Southeast Asia). Cureus. 2016;8(6):e661.

\section{Publisher's Note}

Springer Nature remains neutral with regard to jurisdictional claims in published maps and institutional affiliations. 